\title{
PREVALENCE OF IgG AND IgM ANTI-TOXOPLASMA ANTIBODIES IN PATIENTS WITH HIV AND ACQUIRED IMMUNODEFICIENCY SYNDROME (AIDS)
}

\author{
María de la Luz Galván Ramírez, Virginia Valdez Alvarado, Gustavo Vargas \\ Gutierrez, Octavio Jiménez González, Carlos García Cosio \\ and Marcos Vielma Sandoval
}

\begin{abstract}
With the emergence of the buman immunodeficiency virus (HIV), in patients with acquired immunodeficiency syndrome (AIDS), Toxoplasma gondii has arisen as an important opportunist pathogenic agent, especcially in the central nervous system, being the most common cause of intracerebral lesions. The incidence of Toxoplasma gondii in $H I V$-infected patients depends principally on the existence of latent Toxoplasma parasitosis in the population affected. Through the enzyme-linked immunosorbent assay (ELISA), IgG and IgM anti-Toxoplasma antibodies were found in 92 patients of which 46 (50.0\%) were IgG seropositive, and only one case (1.0\%) had IgM antibodies. Of the 92 patients: 53 were HIV seropositives and 39 had AIDS. The detection and monitoring of anti-Toxoplasma antibodies in HIV patients is essential, since in this group there is a high percentage risk of developing cerebral toxoplasmosis, which is the second cause of death in this type of patients.
\end{abstract}

Key-words: Anti-Toxoplasma antibodies. AIDS. HIV. Toxoplasmosis.

Toxoplasma gondii is one the most common intracelular parasite. While the initial infection and the subsequent chronic one are clinically undetected in $80 \%$ to $89 \%$ of healthy children and adults 1516 , in immunosuppressed patients, especially those infected with the human immunodeficiency virus (HIV), both acute and recurrent toxoplasmosis severe clinical manifestations1 25916 .

In the past, cerebral toxoplasmosis was considered a relatively rare disorder, but with the emergence of HIV, the incidence of toxoplasmosis has risen considerably, causing abscesses and encephalitic toxoplasmosis, resulting from the progressive deterioration caused by a previous latent infection in the brain 49 , although the clinical manifestations are observed in proportion to the diminished number of T lymphocytes 10 11. Another pathology caused by Toxoplasma gondii in this type of patient is ocular toxoplasmosis that occurs in $82 \%$ of the cases 35 . In HIV patients without previous exposure to Toxoplasma gondii the

Centro de Investigación en Enfermedades Tropicales de la Universidad de Guadalajara, Mexico.

Address to: Dr ${ }^{\mathrm{a}}$ Maria de la Luz Galván Ramírez., Centro de Investigación en Enfermedades Tropicales de la Universidad de Guadalajara Lago Camecuaro Num. 2398 Col. Lagos del Country, CP: 44177 Guadalajara, Jalisco, Mexico Fax: 91 (36) 179935.

Recebido para publicação em 10/06/96 acute infection could not be well controlled, and in these susceptible hosts the parasite could rapidly disseminate, producing dermatitis, pneumonitis, myocarditis, hepatosplenomegaly5, and also invade the colon 10 .

The incidence of Toxoplasma gondii in patients infected with HIV depends mainly on the existence of latent anti-Toxoplasma antibodies in the population affected 6 . Serological studies have demonstrated that $15 \%$ to $68 \%$ of adults in the United States and 90\% of adults in some European communities show latent Toxoplasma gondii infection 10 16, which is attributed to geographic differences, feeding habits of eating raw or badly cooked meat, as well as foods contaminated with cat feces containing Toxoplasma gondii oocysts 16 . In the U.S. it is estimated that $20 \%$ to $47 \%$ of all the patients with HIV develop encephalitis caused by toxoplasmosis and $25 \%$ to $50 \%$, in Europe and Africa6 71011 12 13. In Brazil in the patients who die from acquired immunodeficiency syndrome (AIDS), the principal pathogen that damage the CNS is Toxoplasma gondiilt

In Mexico and in our community the prevalence of anti-Toxoplasma antibodies in patients with HIV positive and AIDS is unknown. Because of the risk of damage to the CNS and the high morbidity of this type of patients, we believe it is of utmost importance 
Galván RML, Alvarado VV, Gutierrez GV, González OJ, Cosio CG, Sandoval MV. Prevalence of IgG and IgM anti-Toxoplasma antibodies in patients with HIV and acquired immunodeficiency syndrome (AIDS). Revista da Sociedade Brasileira de Medicina Tropical 30:465-467, nov-dez, 1997.

to find out the prevalence of anti-Toxoplasma antibodies in AIDS patients.

\section{MATERIAL AND METHODS}

In a period of six months 92 sera were included in this study of which 53 corresponded to HIV-positive patients (HIV), 39 had acquired immunodeficiency syndrome (AIDS). Through the immunoenzyme assay (ELISA), of Platest Menarini diagnostics Company TXG029 and TGM030), IgG and IgM anti-Toxoplasma antibodies were detected.

Questionnaire. The following variables were taken into account: sex, age, and clinical diagnosis.

\section{RESULTS}

The age range was from 17 to 69 years old, with an average of 34 years and standard deviation of 10.34. The seropositivity distribution according to the age groups is shown in Table 1. In terms of sex, out of 92 patients, 84 (91.3\%) were male and $8(8.7 \%)$ were female.

The seropositivity of IgG anti-Toxoplasma antibodies was 46/92 (50\%) and there was only one case (1.0\%) with IgM antibodies. In the sera of AIDS-diagnosed patients we found $27 / 39(69.2 \%)$ wiht IgG and no case of IgM anti-Toxoplasma antibodies, and in the HIV+ patients anti-Toxoplasma IgG antibodies were found in 19/53 (35.8\%) with a case of IgM.

Table 1 - Seroprevalence of anti-Toxoplasma gondii antibodies according to age group.

\begin{tabular}{|c|c|c|c|c|}
\hline \multirow[t]{2}{*}{$\overline{\text { Age }}$} & \multicolumn{2}{|c|}{ IgG positive } & \multicolumn{2}{|c|}{ IgM positive } \\
\hline & $\mathrm{n}^{\mathrm{O}}$ & $\%$ & $\mathrm{n}^{\mathrm{o}}$ & $\%$ \\
\hline$<20$ & 1 & 1.1 & 0 & 0.0 \\
\hline $20-29$ & 17 & 18.6 & 0 & 0.0 \\
\hline $30-39$ & 20 & 21.9 & 0 & 0.0 \\
\hline $40-49$ & 2 & 2.2 & 1 & 1.0 \\
\hline $50-59$ & 3 & 3.3 & 0 & 0.0 \\
\hline$>60$ & 3 & 3.3 & 0 & 0.0 \\
\hline Total & 46 & & 1 & \\
\hline
\end{tabular}

\section{DISCUSSION}

The results obtained show that AIDS patients have a greater percentage of anti-Toxoplasma gondii IgG antibodies, possibly because their immudeficiency is very advanced and because of diminished $\mathrm{CD} 4+$ as other researchers have described 91011 . The presence of IgG antibodies in HIV+ and AIDS patients can be due to reactivations of Toxoplasma gondii of a previous endogenous infection, such as other authors have considered9 101116 .

For IgM antibodies we only found one case (1.0\%) with an infection that possibly was recently acquired, a result similar to that in other population groups $(0.75)^{6}$.

The greatest number of seropositive cases was found in the 20 to 39 age group, since the vast majority of AIDS and HIV infected fall into this age range.

In the results obtainde, the seroprevalence of anti-Toxoplasma antibodies was greater in AIDS patients, and 50\% of these can develop cerebral toxoplasmosis, as other researchers have pointed aout 715 16. Therefore, the diagnosis of toxoplasmosis and immediate treatment in these patients is essential.

\section{RESUMO}

Com a aparição do vírus de inmunodeficiência bumana (VIH), a prevalência de toxoplasmosis tem aumentado demais. Em dos pacientes com o sindrome de inmunodeficiência, a toxoplasmosis é a principal causa de morte. A incidência, de anticorpos nesse tipo de pacientes depende da prevalência da população onde se apresenta a doença. O método de Enzima Inmuno Ensaio absorvemnte (ELISA) foi aplicado a 92 pacientes para determinar si eram positivos a anticorpos antiToxoplasma IgG e IgM. O resultado foi: 46 (50.5\%) foram seropositivos e un caso apresentou anticorpos IgM. D estos 92 pacientes, 53 apresentavam o virus de inmunodeficiência humana (HIV) y 39 tinham SIDA. A determinação e o "monitoreo" de anticorpos anti-Toxoplasma em pacientes com HIV é indispensável, pois uma taxa elevada destos pacientes pode desenvolver a toxoplasmosis cerebral, a causa principal de morte nessos pacientes.

Palavras-claves: Anticorpos anti-Toxoplasma. SIDA. HIV. Toxoplasmosis.

\section{REFERENCES}

1. Bolao F, Podzamczer D, Guidiol, Rosenblum M, Niedzwiecki D, Armstrong DF. Toxoplasmosis en pacientes con infección por el HIV. Diagnóstico y Tratamiento Enfermedades Infecciosas y Microbilogía Clínica 8:376-383,1990.

2. Chan JC. Toxoplasmosis in the central nervous system.Annals of Internal Medicine 100:616, 1984.

3. Cochereau MI, LeHoang P, Lautier FM, Zerdoun E, Zazoun L, Robinet M, Marcel P, Girard B, 
Galván RML, Alvarado VV, Gutierrez GV, González OJ, Cosio CG, Sandoval MV. Prevalence of IgG and IgM anti-Toxoplasma antibodies in patients with HIV and acquired immunodeficiency syndrome (AIDS). Revista da Sociedade Brasileira de Medicina Tropical 30:465-467, nov-dez, 1997.

Katlama Ch, Leport C, Rozenbaum W, Coulaud JP, Gentilini M. Ocular toxoplasmosis in human inmmunodeficiency virus infected patients. The American Journal of Ophtalmology 114:130-135,1992.

4. Ferrer CM, Cardenas CM, Cartier RL. Abseso cerebral por Toxoplasma gondii y SIDA. A propósito de un caso con etudio anatomopatológico. Revista Médica de Chile 121:10361041,1993 .

5. Gellin BG, Soave R. Coccidian infections in AIDS. The Medical Clinical of North America 76:205211,1992 .

6. Grant HI, Gold JW. Toxoplasma gondii serology in HIV-infected patients, the development of central nervous system toxoplasmosis in AIDS. AIDS 6:519-521,1990.

7. Holliman RE. Serological study of the prevalence of toxoplamosis in asympotamatic patients infected with human immunodeficiency virus. Epidemiology Infectious 105:415-418,1990.

8. Klein RS, Larroco A, Bretagne S Gray F. Central nervous system toxoplasmosis in AIDS. New England Journal of Medicine 328:1352-1354,1993

9. Luft BJ, Remington JS. Toxoplasmic encephalitis in AIDS. Clinical Infections Diseases 15:211222,1992.

10. Pauwels A, Meyohas MC, Eliaszewicz M, Legendre C, Mougeot G, Frottier J. Toxoplasma colitis in the acquired imunodeficiency syndrome. American Journal of Gastroenterology 87:518-519,1992.

11. Peterson KP, Geekker G, Shuxian Hu. Intracelular survival and multiplicaction of Toxoplasma gondii in astrocytes. Journal Infectious Diseases 168:1472-1478,1993.

12. Porter SB, Sande MA. Toxoplasmosis of the central nervous system in the acquired immunodeficiency syndrome. New England Jorunal of Medicine 327:1643-1648, 1993.

13. Reparaz PJ, Regalados DCJ, Urix Y, Ayestran J. Lesiones cerebrales pacientes con sindrome de inmunodeficiencia adqurida. Enfermedades Infecciosas y Microbilogía Clínica 9:85-89, 1991.

14. Wainstein MU, Ferreira L, Wolfenbuttel L, Golbspan L, Sprint E, Kronfeld M, Edelweiss MIA. Achados neuropatológicos na síndrome da imunodeficiência adquirida (SIDA). Revisão de 138 casos. Revista da Sociedade Brasileira de Medicina Tropical 25:95-99, 1992.

15. Wong SY, Remington JS. Biology of Toxoplasma gondii. AIDS 7:299-316, 1993.

16. Zufferey J, Sugar A, Rudaz P, Bille J, Glauser MP, Chave JP. Prevalence of latent Toxoplasmosis and serological diagnosis of active in HIV-positive patients. Europal Jorunal Clinical Microbilogy Infection Diseases 12:591-595,1993. 